\title{
Extraction, Purification and Characterization of Fish Pepsin: A Critical Review
}

\author{
Lisha Zhao, Suzanne M Budge, Abdel E Ghaly*, Marianne S Brooks and Deepika Dave \\ Department of Process Engineering and Applied Science, Dalhousie University, Halifax, Nova Scotia, Canada
}

\begin{abstract}
The current disposal of fish processing waste is causing environmental problems that have become an issue of public concern. Fish waste could be utilized for production of animal feed, biodiesel, natural pigments, food products and pharmaceuticals.Major attention was also directed to the recovery of valuable biomolecules such as collagen $\omega,-3$ fatty acid, trypsin, chymotrypsin and elastase. Among these molecules, pepsin is one of the most beneficial and useful biomolecule that can be recovered from fish wastes.Pepsin is important aspartic proteases with many unique characteristics. It has several industrial applications including collagen extraction, cheese making, fish silage making, fish processing as well as use in medical research. Fish pepsin is primarily present in fish stomach and has a characteristic $\mathrm{pH}$ optimum of $2.0-4.0$, distinct $\mathrm{pH}$ stability $\leq 6.0$, a distinct optimum temperature of $30-55^{\circ} \mathrm{C}$ and specific thermal stability $\leq 40-50^{\circ} \mathrm{C}$. Pepstatin A can strongly inhibit the pepsin activity while PMSF, E-64 and EDTA have a negligible impact. SDS, cysteine and aliphatic alcohols, have been identified as effective inhibitors while ATP, molybdate, $\mathrm{NaCl}, \mathrm{MgCl}_{2}$, and $\mathrm{CaCl}_{2}$ do not inhibit the activity of pepsin. Pepsin is widely applied in collagen extraction, in digestibility therapy, as rennet substitute and. At present, conventional method and innovative method have been developed for fish pepsin recovery. In the conventional method (ammonium sulfate), the partition of pepsinogen ( $P G$ ) is mainly based on (a) crude enzyme extraction by homogenization and centrifugation, (b) purification of PG by gel filtration and anion exchange chromatography and (c) activation of PG under the acidic condition. The innovative recovery is based on aqueous two-phase system (ATPS). The conventional method is used for high purification while the ATPS is used for partial purification. Enzyme activity and concentration, specific activity (SA), purification factor (PF), molecular weight, and homogeneity, isoelectric point ( $\mathrm{pl}$ ) and are used to assay fish pepsin.
\end{abstract}

Keywords: Fish; Pepsin; Dimensional structure; pH; Stability; Temperature; Inhibitor; Partition; Conventional methods; Aqueous two phase system; Assay

\section{Introduction}

The growing consumer demand for healthyfish products has led toa thriving fish processing industry worldwide. Processing of fish includes: scaling, cutting, filleting, cooking, salting and canning. When fish fillets or cans are produced, a large fraction (30-80\%) of fish (flesh, heads, bones, fins, skin, tails and viscera) is left as waste. Fish waste is usually disposed off in landfills or in the sea resulting in environmental problems which underscore the need for a proper utilization of fish wastes for the recovery of valuable products. Fish waste can be utilized as ingredient in animal feed and fertilizer [1,2] or used for the recovery of valuable biomolecules such as collagen [3,4] $\omega-3$ fatty acid [5] trypsin [6,7] chymotrypsin [8] and elastase [9] or the production of biodiesel [10].

Pepsin is an important acidic protease that is widely applied in the hydrolysis of proteins. It is used in collagen extraction [11-13] in gelatin extraction [14] as a rennet substitute [15] and in digestibility therapy [16]. Pepsin has been isolated and investigated from various mammals including: human [17] Japanese monkey [18] pig [19] bovine [20] goat [21] rat [22] and rabbit [23]. Pepsin can also be recovered from fish wastes, especially fish viscera which constitute $5 \%$ of fish weight [24]. Isolation and purification of pepsin from fish and fish wastes is less developed. Thus, an efficient and economic process for the isolation and purification of pepsins from fish wastes would bring significant economic and environmental benefits for both the fish processing and pepsin industries.

\section{Structures, Sources and Classification of Pepsin}

Pepsin (molecular weight of $36 \mathrm{k} \mathrm{Da}$ ) is an enzyme in the aspartic protease family which digests proteins. Peptide bonds can be readily cleaved allowing degradation of proteins under acidic conditions [25]. Pepsin can be found primarily in the gastric juice of the stomach lumen and can be isolated from a variety of species such as human, cattles, sheeps, birds and fish [26,27]. The main location of pepsin in mammals is the stomach (both the membrane and the gastric juice) but it can also be found in limited amounts in the blood, muscle and the urine [27]. Fish pepsins are mostly present in the stomach but can also be found in theovaries of brook trout or the skin of puffer fish [28,29]. There are several types of stomach pepsins, each has a distinct protein structure and enzymatic properties [30].

Pepsin is synthesized and secreted in the gastric membrane in an inactive state called pepsinogen (PG) (molecular weight of $40 \mathrm{kDa}$ ). Compared with pepsin, pepsinogen contains an additional 44 amino acids and is stable in neutral and weak alkaline environments, but when exposed to the hydrochloric acid $(\mathrm{HCl})$ present in gastric juice $\left(\mathrm{p}^{\mathrm{H}}\right.$ of $\left.1.5-2.0\right)$, the 44 amino acids are proteolytically removed in an autocatalytic way to activate it to pepsin [31]. Its main role in protein proteolysis is to cleave aromatic amino acids (such as phenylalanine and tyrosine) from the $\mathrm{N}$-terminus of proteins [31].

*Corresponding author: Abdel E Ghaly, Professor, Department of Process Engineering and Applied, Science, Dalhousie University, Halifax, Nova Scotia, Canada, Tel: (902) 494-6014; E-mail: abdel.ghaly@dal.ca

Received September 24, 2011; Accepted November 15, 2011; Published November 17, 2011

Citation: Zhao L, Budge SM, Ghaly AE, Brooks MS, Dave D (2011) Extraction, Purification and Characterization of Fish Pepsin: A Critical Review. J Food Process Technol 2:126. doi:10.4172/2157-7110.1000126

Copyright: @ 2011 Zhao L, et al. This is an open-access article distributed under the terms of the Creative Commons Attribution License, which permits unrestricted use, distribution, and reproduction in any medium, provided the original author and source are credited. 
The three-dimensional structures of pepsin and pepsinogen from fish species are shown in Figure 1. While mammal pepsin has been completely sequenced, fish pepsin has not been extensively explored. The first proposed three-dimensional structure for cod pepsin was identical to porcine pepsin in domain location and amino acid formation (57.7\% sequence identity) [32,33]. Cod pepsin is reported as a single chained protein (a monomer) of two similar folded domains separated by a deep cleft [32]. The catalytic site of pepsin is formed at the junction of the domains and contains two aspartic acid residues, Asp 32 and Asp 215 in each domain [33,34]. In the catalysis of pepsin, water molecule helps between the active carboxyls and Asp 215 and Asp 32 becomes negatively and positively charged individually to break peptide bonds in proteins $[35,36]$.

The nomenclasture and classification of pepsin depends primarily on the enzyme characteristics including activity, stability and kinetics [2,37-39] and properties of enzyme including aspartate residues for the catalysis of substrates, protein degradation and the tertiary structure [36,40-42]. Mammalian pepsinogens (PGs) are divided into two groups: (a) a major group which includes pepsinogen A (PG-A), pepsinogen $\mathrm{C}$ (PG-C, or progastricsin) and pepsinogen $\mathrm{Y}$ (PG-Y or prochymosin) and (b) a minor group which includes pepsinogen $B$ (PG-B) and pepsinogen F (PG-F) $[23,41,43,44]$. Classification of fish

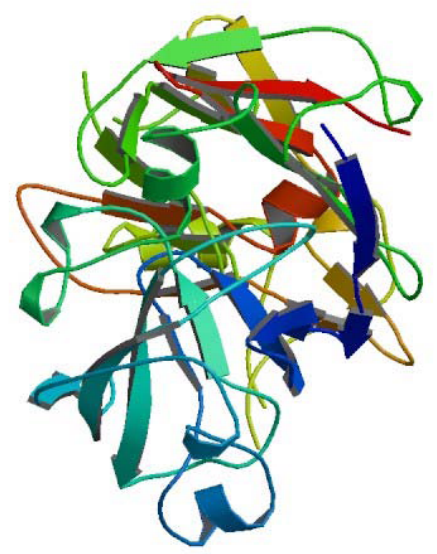

(a) Pepsin from Atlantic Cod (Gadusmorhua)

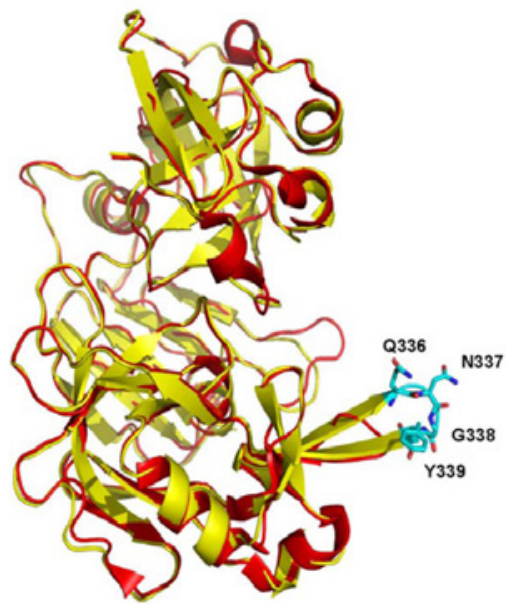

(b) Pepsinogen from golden mandarin fish (Sinipercascherzeri)

Figure 1: Three-dimensional structures of pepsin [32] and pepsinogen [40]. pepsinogen varies among researchers. Some researchers followed the mammal pepsin classification system and divided fish pepsinogens to PG-A, PG-B and PG-C [45-48] while others divided fish pepsinogens to PG-I, PG-II, PG-III and PG-IV [30,49-52]. However, fish PGs have distinct characteristics from mammalian PGs [53] including higher $\mathrm{pI}$ [54] higher $\mathrm{pH}$ optimum and Michaelis constant [55] lower optimum temperature and thermal stability [56] than mammalian PGs.

Fish PGs (or pepsins) have been purified and characterized in various types of fishes including Arctic capelin [48] rainbow trout [57] Atlantic cod [58] bolti fish [2] Antarctic rock cod [59] sea bream [51] African coelacanth [49] Mandarin fish [60] smooth hound [50] orange-spotted grouper [47] albacore tuna [61] and European eel [52]. The amounts and types of PGs vary among fish species as different fish species have different PG isoforms in the stomachs. Bougatef et al. [50] isolated only one type of PGs from the stomach of smooth hound and obtained 7.33mg of PGs/100g stomach. Gildberg and Raa [48] isolated two pepsins (pepsins I and II) from the Arctic capelin and obtained 13.9 and $0.5 \mathrm{mg}$ per 100 gastric membranes, respectively. Tanji et al. [49] isolated three types of PGs (PGs I, II and III) from the stomach of African coelacanth and obtained 12.1, 8.57 and $16.7 \mathrm{mg}$ per $100 \mathrm{~g}$ stomach mucosa, respectively. Wu et al. [52] isolated three types of PGs (PGs I, II and III) from the stomach of European eel and obtained 3.63 mg per 100g stomachs. Zhou et al. [51] found four types of PGs in sea bream stomachs with a total amount of $35.5 \mathrm{mg}$ per $100 \mathrm{~g}$ stomach. Zhou et al. [60] isolated four PGs from the mucosa of mandarin fish with a total amount of $36.6 \mathrm{mg} / 100 \mathrm{~g}$ stomach. However, among all the fish pepsins, pepsins from cod and tuna are the most investigated.

Cod pepsins have been studied and sequenced by many researchers [39,46,59,61-63]. Gildberg [53] reported that cod (cold water fish) has pepsins which are more active at low temperature than those from warm water fishes. He also indicated that a high content of pepsin (50-100 mg pepsin per $100 \mathrm{~g}$ cod stomach) is found in Atlantic cod. Bjelland et al. [64] found two different types of pepsins in cod (Pepsin I and Pepsin II) which are similar to mammalian pepsins in structure but are more active at low temperatures and weak acid conditions and more easily inactivated by moderate heating as cod is more adaptable to cold temperature compared to mammals which are usually live in warm habitats. Gildberg et al. [46] indicated that pepsin I functions under relatively weak acidic condition $\left(\mathrm{p}^{\mathrm{H}}=4.0\right)$ while pepsin II has a similar $\mathrm{pH}$ optimum to mammalian pepsin and more active in strong acidic condition $\left(\mathrm{p}^{\mathrm{H}}=2.0\right)$. Gildberg [56] reported higher content of basic amino acids present in fish pepsin I and explained the difference. Brier et al. [59] reported similar results with these two types of pepsins and noted that they have greater sensitivity to inhibitors such as pepstatin, which is probably attributed to changes in the sequence of fish pepsin near the active site.

Albacore tuna have only one type of pepsin [65]. Tongol tuna contains two isoforms of pepsin while only one type of pepsin was found in skipjack tuna stomach [66]. Nalinanon et al. [65] indicated that pepsin in tuna has a molecular weight and an active temperature that are different from those of bovine pepsin. Tanji et al. [67] detected three PGs (PG-I, PG-II and PG-III) in Pacific blue fin tuna, which contain a greater number of basic residues than mammalian PGs and are found to be most active at a $\mathrm{p}^{\mathrm{H}}$ of 2.5.Tuna pepsins I and II can be greatly inhibited by the protease inhibitor pepstatin A $[65,67]$. Tanji et al. [44] indicated that pepsins in blue fin tuna have unique properties and functions which are diverse than pepsins from other fish species. Pepsin from yellow fin tuna has an optimum temperature of $45^{\circ} \mathrm{C}$, an 
optimum $\mathrm{p}^{\mathrm{H}}$ of 2.5 and crystal structure, specificity, alkaline stability and other properties which are different from swine pepsins [68].

\section{Factors Affecting the Activity of Pepsins}

The activity of pepsin measured by its ability to hydrolyze proteins is influenced by $\mathrm{p}^{\mathrm{H}}$, temperature and inhibitors.

\section{pH}

Both the optimum $\mathrm{pH}$ (the $\mathrm{pH}$ value giving the highest enzymatic activity) and $\mathrm{pH}$ stability (the $\mathrm{pH}$ range giving good enzyme stability) have significant effects on the activity of fish pepsin. When the $\mathrm{pH}$ deviates from the optimum value, the activity of pepsin drops. ElBeltagy et al. [2] reported that pepsins I and II from bolti fish had the same optimum $\mathrm{pH}$ of 2.5 and deviation from that $\mathrm{pH}$ value resulted in reduced activity (Figure 2). A summary of optimum $\mathrm{pH}$ values for pepsin from different fishesis displayed in Table 1. In general, if the fish has more than one type of pepsin, their optimum $\mathrm{pH}$ will be similar. However, this fact does not apply to some fishes such as Arctic capelin [48]. Generally, pepsin stability is mentioned at lower $\mathrm{pH}$ values. Pepsin is a type of acidic protease and depression of its stability is attributed to the denaturation of proteins above the $\mathrm{pH}$ of 6.0 [61]. Klomklao et al. [45] studied the effect of $\mathrm{pH}$ on the pectoral rattail pepsins and found that pepsin $\mathrm{A}$ and pepsin $\mathrm{B}$ were stable in the $\mathrm{pH}$ range of 2-6 and their activities dropped dramatically when the $\mathrm{pH}$ exceeded 6 . Nalinanon et al. [65] found albacore tuna pepsin was stable within the $\mathrm{pH}$ range of $2-5$. Similar results were reported with several fish pepsins $[48,64,69$ $71]$.

\section{Temperature}

Temperature has a great influence on the activity of fish pepsin. Like $\mathrm{pH}$, the optimum temperature and thermal stability range are very important. A summary of optimum temperature for fish pepsin is displayed in Table 2. The optimum temperature of fish pepsin ranges from 30 to $55^{\circ} \mathrm{C}$. When the temperature deviates from the optimum value, the activity of pepsin drops. The optimum temperature of fish pepsin depends greatly on fish species (cold or warm water species) $[30,64,72,73]$. Fishes from cold water habitats have lower optimum temperature than those from warm water habitat $[61,64,70]$. The activities of pepsins I and II from warm water sardine had relatively

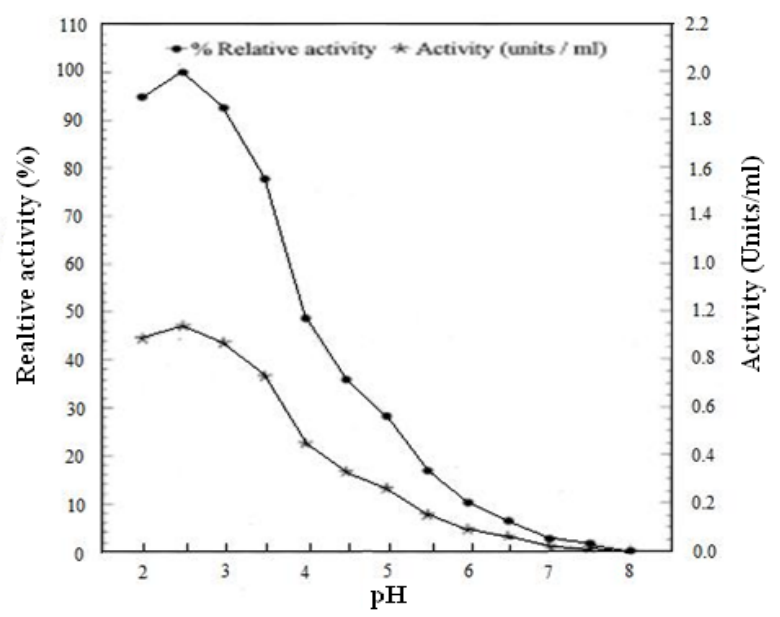

Figure 2: Effect of $\mathrm{p}^{\mathrm{H}}$ on the activity of pepsins I and II from bolti fish Tilapia nilotica [2].

\begin{tabular}{|c|c|c|c|}
\hline Enzyme & Identified Species & Optimum $p^{H}$ & Reference \\
\hline Pepsin & Smooth hound & 2.0 & Bougatef et al. [50] \\
\hline Pepsin I & Arctic capelin & 3.7 & Gildberg and Raa [48] \\
\hline Pepsin II & Arctic capelin & 2.5 & Gildberg and Raa [48] \\
\hline Pepsin I & European eel & 3.5 & Wu et al. [52] \\
\hline Pepsin II & European eel & 2.5 & Wu et al. [52] \\
\hline Pepsin III & European eel & 2.5 & Wu et al. [52] \\
\hline Pepsin & Greenland cod & 3.5 & Squires et al. [61] \\
\hline Pepsin & Atlantic cod & 3.5 & Haard [62] \\
\hline Pepsin & Arctic cod & 3.0 & Haardet al. [72] \\
\hline Pepsin I & Atlantic cod & 3.5 & Gildberg [58] \\
\hline Pepsin II & Atlantic cod & 3.0 & Gildberg [58] \\
\hline Pepsin & palometa & $3.0-3.5$ & Pavliskoet al. [73] \\
\hline Pepsin I & Sea bream & 3.0 & Zhou et al. [51] \\
\hline Pepsin II & Sea bream & 3.5 & Zhou et al. [51] \\
\hline Pepsin III & Sea bream & 3.5 & Zhou et al. [51] \\
\hline Pepsin IV & Sea bream & 3.5 & Zhou et al. [51] \\
\hline Pepsin & Albacore tuna & 2.0 & Nalinanon et al. [65] \\
\hline Pepsin I & Mandarin fish & 3.5 & Zhou et al. [60] \\
\hline Pepsin II & Mandarin fish & 3.5 & Zhou et al. [60] \\
\hline Pepsin III & Mandarin fish & 3.5 & Zhou et al. [60] \\
\hline Pepsin IV & Mandarin fish & 3.5 & Zhou et al. [60] \\
\hline Pepsin I & African coelacanth & 2.0 & Tanji et al. [49] \\
\hline Pepsin II & African coelacanth & 2.0 & Tanji et al. [49] \\
\hline Pepsin III & African coelacanth & 2.5 & Tanji et al. [49] \\
\hline
\end{tabular}

Table 1: The optimum $\mathrm{p}^{\mathrm{H}}$ of pepsin from different fishes.

high temperature optima of $40^{\circ} \mathrm{C}$ and $55^{\circ} \mathrm{C}$, respectively [70] while pepsins I and II from cold water Arctic capelin showed the greatest activity at 38 and $43{ }^{\circ} \mathrm{C}$, respectively [48]. Every type of pepsin has unique thermal properties and enzymes from cold water species have relatively low optimum temperatures. Simpson and Haard [74] stated that cold water fish enzymes have a low Arrhenius activation energy which explains their low optimal temperatures and high heat liability compared with warm water counterparts. Haard [54] indicated that genes in different fish species account for the diversity of the enzymic characteristics.

The upper temperature limit for pepsin stability depends on the type of fish. However, pepsins from cold water species are quite susceptible to higher temperatures [49,57-59]. Nalinanon et al. [65] reported that pepsin from albacore tuna (a type of warm water fish that can adapte to waters with $13.5-25.2^{\circ} \mathrm{C}$ ) retained its stability at temperatures ranging from 20 to $50^{\circ} \mathrm{C}$ and the stability of pepsin decreased significantly when the temperature increased above $50^{\circ} \mathrm{C}$. Bolti fish remained stable below $60^{\circ} \mathrm{C}$ [2] and Monterey sardine was active below $45^{\circ} \mathrm{C}$ [71]. The upper temperature limit for pepsins from other warm water species such as dogfish, pectoral rattail and smooth hound are $50^{\circ} \mathrm{C}, 40^{\circ} \mathrm{C}$ and $50^{\circ} \mathrm{C}$, respectively $[45,50,75]$. The sharp decrease of thermal stability is attributed to the denaturation of pepsin and destruction of its structure above temperature upper limit $[62,65,76]$.

\section{Inhibitors}

Pepstatin A (a typical aspartic proteinase inhibitor) can combine with fish pepsin and prevents the binding of the enzyme to substrate, 
thereby resulting in a complete inhibition of its activity [36,51,52,77]. Pepstatin A is a peptide isolated from several species of actinomyces, such as Streptomyces spp [78]. Ithas one of the lowest known inhibition constant $(\mathrm{Ki}=45 \mathrm{pM})$ for pepsin [77,79]. Zhou et al. [51] studied the inhibitory effect of pepstatin on sea bream fish pepsin and found that the pepstatin formed a complex with Pepsins I, II, III and IV at different pepstatin: pepsin ratios. This molar pepstatin to pepsin ratio played an essential role in the inhibition. According to Bougatef et al. [50] a ratio of about 1:1 gave an entire inhibition of mandarin fish pepsins III and IV while a ratio of 10:1 was necessary to inhibit pepsins I and II. Pepsin from smooth hound was found to be completely inhibited with a molar pepstatin: pepsin ratio of 16:1. Molar pepstatin: pepsin ratios for bluefin tuna, two pepsins from bullfrog and two pepsins from Antarctic rock cod were found to be $17: 1,17: 1$ and $1: 1$, respectively $[59,67,80]$.

Not every protease inhibitor has an inhibitory effect on pepsin. It has been shown that typical inhibitors such as phenyl methyl sulfonyl fluoride (PMSF) which is a serine proteinase inhibitor; L-3-carboxytrans-2, 3-epoxy-propionyl-L-leucin-4-guanidino-butylamide (E-64) which is a cysteine proteinase inhibitor and Ethylene diamine tetra acetic acid (EDTA) do not have any inhibitory effect on pepsins $[45,50$ $52,71]$. However, some chemicals have inhibitory effects on the activity of fish pepsin. Sodium dodecyl sulfate (SDS) at $0.05-0.10 \%(\mathrm{w} / \mathrm{v}) \mathrm{had}$ a strong inhibitory effect on the activity of pepsins from albacore, skipjack and tongol tunas while cysteine (5-50 mM) showed some inhibitory effects on them [66]. Aliphatic alcohols (methanol, ethanol, amylalcol) inhibit the activity of pepsin at low concentrations. The inhibition of pepsin by iso amyl alcohol occurs at concentration less than $0.09 \mathrm{M}$ [81]. Adenosine tri phosphate (ATP), molybdate, $\mathrm{NaCl}$, $\mathrm{MgCl}_{2}$, and $\mathrm{CaCl}_{2}$ do not have any impact on the activity of pepsins from albacore tuna [65] skipjack tuna and tongol tuna [66] turbot [82] and pectoral rattail [45].

\section{Industrial Application of Pepsins}

\section{Collagen extraction}

Conventionally, collagen is extracted by an acid-solubilization process (ASP) in which collagen is solubilized in an acid (such as acetic acid) and other non-acid-soluble materials are removed [37]. Since pepsin can break down cross-linkages in the telo peptide regions of collagen without harming to its secondary structure, the use of pepsin in this process can effectively enhance the yield of collagen [11,13,37] Nagai and Suzuki [3] and Nagai et al. [83] used mammalian pepsin in collagen extraction and found significance increases in collagen yield. Fish pepsins havebeen used in collagen extraction by several researchers. Nalinanon et al. [13] reported that with addition of the same fish pepsin the yield of collagen from the skin of big eye snapper (Priacanthustayenus) increased to $18.7 \%$ compared with a

\begin{tabular}{|c|c|c|c|c|}
\hline Enzyme & Identified Species & Habitat & Optimum Temperature $\left({ }^{\circ} \mathrm{C}\right)$ & Reference \\
\hline Pepsin I & Sardine & Warm water & 55 & Noda and Murakami [70] \\
\hline Pepsin II & Sardine & Warm water & 40 & Noda and Murakami [70] \\
\hline Pepsin I & Arctic capelin & Cold water & 38 & Gildberg and Raa [48 \\
\hline Pepsin II & Arctic capelin & Cold water & 43 & Gildberg and Raa [48] \\
\hline Pepsin I & European eel & Warm water & 40 & Wu et al. [52] \\
\hline Pepsin II & European eel & Warm water & 40 & Wu et al. [52] \\
\hline Pepsin III & European eel & Warm water & 35 & Wu et al.[52] \\
\hline Pepsin & Greenland cod & Cold water & 30 & Squires et al. [61] \\
\hline Pepsin & Arctic cod & Cold water & 32 & Haardet al. [72] \\
\hline Pepsin & Polar cod & Cold water & 37 & Arunchalam and Haard [76] \\
\hline Pepsin I & Atlantic cod & Cold water & 40 & Gildberg [58] \\
\hline Pepsin II & Atlantic cod & Cold water & 40 & Gildberg [58] \\
\hline Pepsin & Palometa & Warm water & 37 & Pavliskoet al. [73] \\
\hline Pepsin I & Sea bream & Warm watera & 45 & Zhou et al. [51] \\
\hline Pepsin II & Sea bream & Warm water & 50 & Zhou et al. [51] \\
\hline Pepsin III & Sea bream & Warm water & 50 & Zhou et al. [51] \\
\hline Pepsin IV & Sea bream & Warm water & 50 & Zhou et al. [51] \\
\hline Pepsin & Albacore tuna & Warm water & 50 & Nalinanonet al. [65] \\
\hline Pepsin I & Mandarin fish & Warm water & 40 & Zhou et al. [60] \\
\hline Pepsin II & Mandarin fish & Warm water & 45 & Zhou et al. [60] \\
\hline Pepsin III & Mandarin fish & Warm water & 40 & Zhou et al. [60] \\
\hline Pepsin IV & Mandarin fish & Warm water & 45 & Zhou et al. [60] \\
\hline Pepsin I & Pectoral rattail & Warm water & 45 & Klomklao et al. [45] \\
\hline Pepsin II & Pectoral rattail & Warm water & 45 & Klomklao et al. [45] \\
\hline
\end{tabular}

Table 2: The optimum temperature of pepsin from different fishes. 
yield of 5.3\% obtained with ASP. Ahmad and Benjakul [84] reported that with the addition of albacore tuna and yellow fin tuna pepsins, the yields of collagen isolated from the skin of unicorn leather jacket (Aluterusmonocerous) were $8.48 \%$ and $8.40 \%$, respectively (which were higher than the $4.19 \%$ obtained with ASP). Nalinanon et al. [66] reported that after $12 \mathrm{~h}$ extraction using pepsins from albacore tuna, skipajack tuna and tongol tuna, $74.48 \%, 63.81 \%$ and $71.95 \%$ of collagen were isolated from the skin of thread fin bream (Nemipterus $s p p$.), respectively. These values were greater than the yield of $22.45 \%$ obtained with ASP.

\section{Medical research}

Pepsin is utilized in regulation of digestion, as a dental antiseptic and in treatment of ailment including dyspepsia, gastralgia, obstinate vomiting, infantile diarrhea, apepsia and some cancer [85]. Combined with $\mathrm{HCl}$, pepsin tablets and capsules have been developed to support the digestibility in the gastrointestinal tract as well as to enhance the appetite of patients [86]. Pepsin from porcine stomach is used for treatment of gastric ulcers with bismuth complexes added [87]. Pepsin is also added for better digestibility of proteins in animals feed.

\section{Cheese making}

Animal (calf, bovine and porcine sources) rennet is composed of pepsin and chymosin commonly mixed in a ratio of 1:9 and used in commercial cheese making. However, their high costs have forced the industry to find new substitutes and fish pepsin has been regarded as one such promising substitute [62,74,88]. Brewer et al. [88] found cod pepsin to have a higher ability to clot milk than calf chymosin at $15^{\circ} \mathrm{C}$ and the prepared cheese had good flavour when tested by a sensory panel. Haard [62] stated that cod pepsin has a lower temperature coefficient (1.4) for milk clotting than that of calf rennet (2.2). Tavares et al. [89] indicated that tuna pepsin is effective as a commercial rennet in cheese production within the $\mathrm{pH}$ range of 5.5 6.5. Despite these promising results, cheese production based on fish pepsin has not yet been commercialized [15,24].

\section{Fish silage}

Fish pepsin can be used in the production of fish silage, a liquefied product of minced fish and fish visera solubilized by endogenous proteo lytic enzymes in the presence ofan acid [90-93]. Pepsin plays a major role among all enzymes in preparation of silage [53]. It can degrade and liquefy minced raw material squickly into highly nutritious protein hydrolysate [53,86,90,94,95]. Gildberg and Almås [91] indicated that pepsins I and II in cod viscera were effectively used for the production of aqueous phase of cod viscera silage under acidic conditions. Goddard and Al-Yahyai [94] reported that good silage was obtained with fresh minced sardine (as a source of pepsin) and formic and propionic acids mixture.

\section{Fish processing}

Fish pepsin can be utilized in gentle processing of some fish raw materials. Pepsin from cold-water species such as Atlantic cod (Gadusmorhua) and orange roughy (Hoplostecthusatlanticus) have been used for caviar production from the roe of the same species in New Zealand [69]. Cod pepsin was tested for deskinning of herring [96] and used to descale hake and haddock under weak acidic conditions [58]. At present, Atlantic cod crude pepsin has been commercialized for the descaling of fish [53].

\section{Partitioning of Pepsin}

The process of partitioning of fish pepsin involves three steps: (a) extraction of pepsinogen which involves preparation of fish stomach and crude extract, (b) purification of pepsinogen and (c) activation of pepsinogen to pepsin. All these steps are conducted at low temperatures $\left(\leq 4^{\circ} \mathrm{C}\right)$ to prevent denaturation of proteins [97]. Purification can be achieved by the conventional method or by the aqueous two-phase system. Three different steps (Figure 3) can be used for purification of pepsinogens (PGs) under the conventional method: ammonium sulphate fraction ation, gel filtration or anion exchange chromatography [50,98-100]. However, if high homogeneity of pepsin is not required and a mixture of several types of pepsins from same fish species with a low level of impurities, pepsin can be extracted and purified using the aqueous two-phase system (ATPS) as shown in Figure 4.

\section{Extraction of pepsinogen}

Preparation of fish stomach (or mucosa): The preparation of fish stomach involves the separation of the stomach or mucosa (a mucous membrane layer of the stomach containing the glands and the gastric pits which are the source of pepsinogen) from other organs in the fish viscera. The stomachs must be stored at a low temperature $\left(-20^{\circ} \mathrm{C}\right.$ or $-80^{\circ} \mathrm{C}$ ) until used in order to minimize the autolysis of proteases [45,47,50,64,65,67,101]. El-Beltagy et al. [2] and Castillo-Yáñez et al. [71] stored the viscera of bolti fish and Monterey sardine at $-20^{\circ} \mathrm{C}$ before they were used for enzyme extraction. Tanjiet al. [102] stored stomachs of North Pacific bluefin tuna at $-80^{\circ} \mathrm{C}$ before extraction.

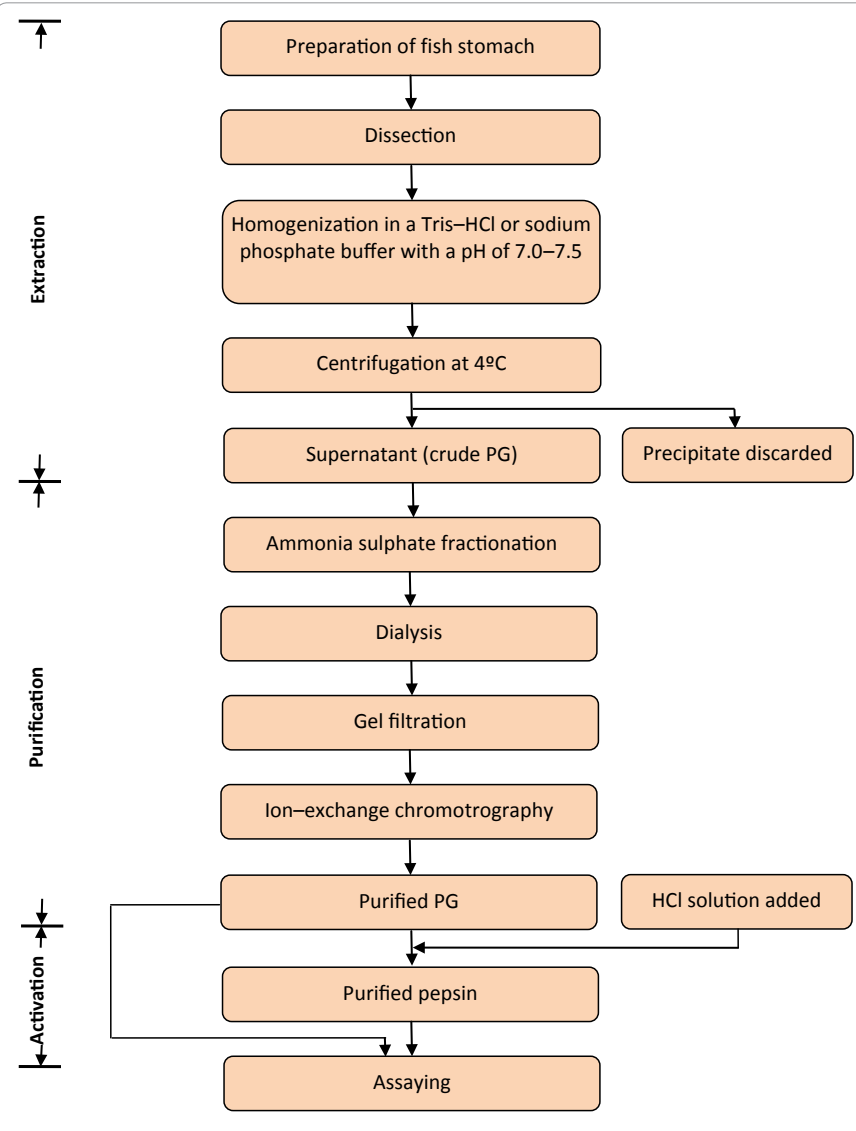

Figure 3: The procedure of conventional method for pepsin recovery [82]. 


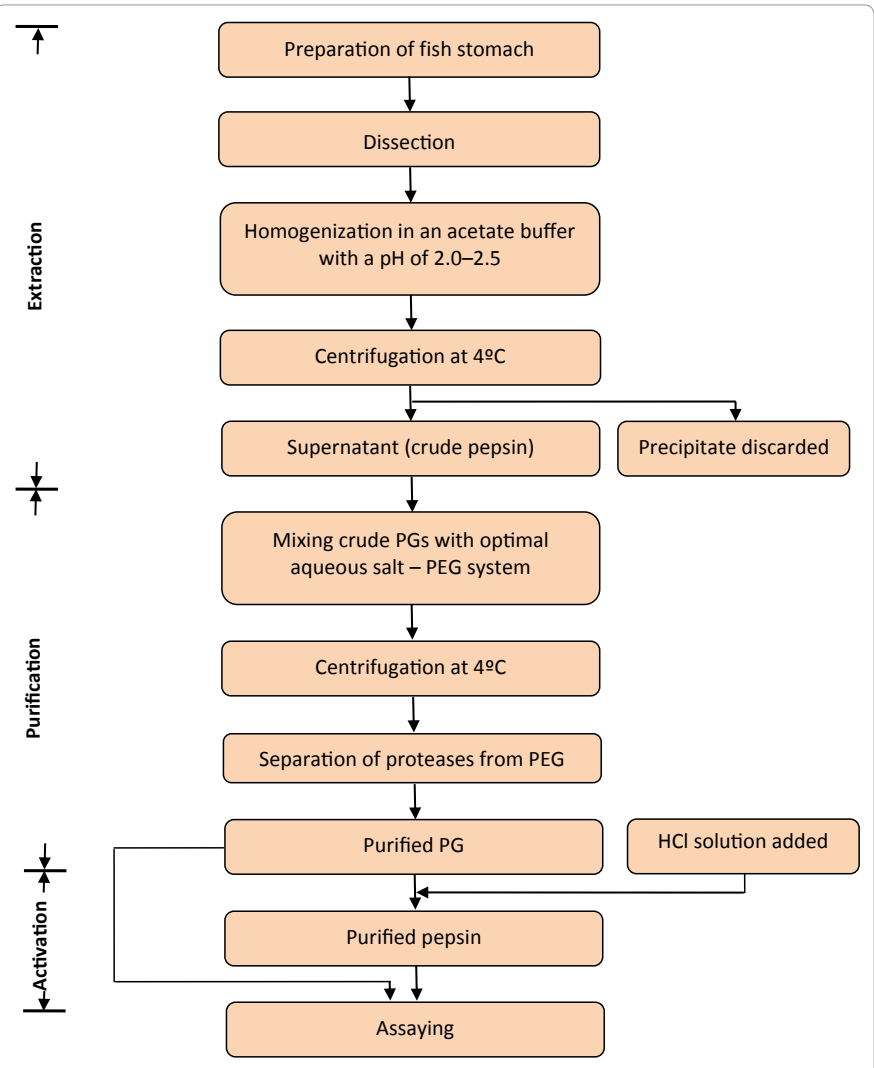

Figure 4: The procedure of ATPS method for pepsin recovery [110].

Gildberg and Raa [48] stored whole Arctic capelin at $-20^{\circ} \mathrm{C}$ before thawing and removal of stomachs. Feng et al. [47] stored whole orangespotted groupers at $-80^{\circ} \mathrm{C}$ before removal of specific organs.

Preparation of crude extract: A variety of methods have been used to isolate the enzymes from stomach mucosa cells, all of which involve three steps: (a) dissection and homogenization of samples to disrupt the cells to release the PGs, (b) solubilization of PGs in an appropriate buffer to control the $\mathrm{pH}$ and maintain PGs stable (c) centrifugation of the mixture to remove the cell residues from PGs. The temperature plays a significant role in crude enzyme recovery and the extraction procedure should be conducted at a low temperature $\left(0-4^{\circ} \mathrm{C}\right)$ to minimize protein denaturation as well as the autolysis of enzymes [103].

The use of buffer solutions is important in PG extraction and their $\mathrm{pH}$ must be controlled at 7.0-7.5 to keep the enzymes stable. Sodium phosphate buffer, Tris- $\mathrm{HCl}$ buffer and distilled water are the most commonly used solvents to extract the crude PG. Twining et al. [57] Pavlisko et al. [73] Zhou et al. [51] Tanji et al. [49] and Wu et al. [52] used sodium phosphate buffers having a $\mathrm{pH}$ in the range of 7.0-7.5 to solublize the enzymes. Brewer et al. [88] Squires et al. [61] Chong et al. [104] Brier et al. [59] and Bougatef et al. [50] used a Tris-HClbuffer with a $\mathrm{pH}$ of 7.5 to solubilize the enzymes. Distilled water was, also, used by Bjelland et al. [64], Gildberg [58], Castillo-Yáñez et al. [71] and Nalinanon et al. [65] as an enzyme solvent.

Doonan [103] stated that the mixing and homogenization operations applied in the preparation of crude extract gave sufficient disruption of mucosa cells and ensured that the released proteins were evenly dissolved in the buffer. Two types of homogenizations have been reported in the literature. Most researchers homogenize the stomachs in a buffer and as such directly release PGs into the buffer solution $[50,57,70,71,82]$. Others homogenize the sample in a liquid nitrogen, freeze-dry it to yield a fine enzyme powder and then solubilize this powder in a buffer $[47,65]$. Another method for the preparation of PG powder involves homogenizing the stomachs in acetone at $-20^{\circ} \mathrm{C}$ and air-drying it at ambient temperature to obtain a fine stomach powder $[2,45,105]$.

Centrifugation is used to remove the insoluble materials from the mixture of enzymes and mucosaresidues and to separate the crude PG. The condition of centrifugation is denoted by the centrifugation field (g), a term used to describe the centrifugation force. Tanji et al. [49] centrifuged a homogenized suspension at $20,000 \mathrm{~g}$ for $20 \mathrm{~min}$ at $4^{\circ} \mathrm{C}$ to separate the crude albacore tuna enzyme. Wu et al. [52] acquired crude PGs of European eels by centrifugation at $18,000 \mathrm{~g}$ for $90 \mathrm{~min}$. Several researchers $[45,48,57,71]$ recommended centrifugation at $15,000 \mathrm{~g}$ for $30 \mathrm{~min}$ or $20,000 \mathrm{~g}$ for $20 \mathrm{~min}$.

\section{Conventional purification methods of pepsinogen}

Ammonia sulfate fractionation: Ammonium sulfate fractionation (ASF) serves as the principal approach to purify enzymes [106]. A mixture of proteins in the supernatant is typically obtained in the centrifugation step, which can be precipitated and separated in $\left(\mathrm{NH}_{4}\right)_{2} \mathrm{SO}_{4}$ solution. Usually, two saturations of $\left(\mathrm{NH}_{4}\right)_{2} \mathrm{SO}_{4}$ solution are applied to achieve purification. Lower saturation (20-30\%) serves to precipitate unwanted proteins, which can be discarded through centrifugation while higher saturation $(60-70 \%)$ is applied to the supernatant for pooling of desired proteins $[97,107]$. Wu et al. [52] and Bougatef et al. [50] used 20-60\% saturation to achieve high purification of European eel and smooth hound PGs, respectively. Gildberg and Raa [48] and Klomklao et al. [45] used 30-70\% saturations to purify PGs from Arctic capelin and pectoral rattail, respectively. El-Beltagy et al. [2] used $40-60 \%$ saturation for the purification of Bolti fish PGs. After this step, dialysis or diafiltration is performed to remove the $\left(\mathrm{NH}_{4}\right)_{2} \mathrm{SO}_{4}$ from the enzyme precipitates [107].

Ion-exchange chromatography: Ion-exchange chromatography (IEC) is used for further protein purification. In this step, proteins (including PGs) are absorbed to stationary phase with oppositely charged molecules with different absorption abilities. As the concentration gradient of eluant is gradually increased, different types of proteins can be eluted and separated $[97,108]$. Selection of the column packing material is essential. Diethyl amino ethyl cellulose (DEAE-cellulose) is the most commonly used for protease purification $[49,50,65,67]$. The buffer used as a solvent in crude enzyme extraction step is applied to equilibrate and wash the column and $\mathrm{NaCl}$ (with an increasing linear gradient of $0-0.5 \mathrm{M}$ ) and the same buffer are used to elute the PGs [65]. Tanji et al. [67] and Tanji et al. [49] used a DEAE-cellulose column eluted by a gradient of $0-0.5 \mathrm{M} \mathrm{NaCl}$ in a sodium phosphate buffer at a flow rate of $0.5 \mathrm{ml} / \mathrm{min}$ for the purification of different types of PGs from African coelacanth and North Pacific bluefin tuna. Bougatef et al. [50] used a DEAE-cellulose column equilibrated by a Tris- $\mathrm{HCl}$ buffer with $0-0.5 \mathrm{M} \mathrm{NaCl}$ to elute the column at a flow rate of $1.3 \mathrm{ml} /$ min for the purification of one type of PG from smooth hound. Wu et al. [52] and Zhou et al. [51] used a DEAE-Sephacel column and a gradient of $0-0.5 \mathrm{M} \mathrm{NaCl}$ in a sodium phosphate buffer to separate different PGs from European eel and Sea bream. The elution proceeds until no further peaks are detected, which means all proteins have been 


\begin{tabular}{|l|l|l|}
\hline Gel Type & $\begin{array}{l}\text { Molecular } \\
\text { Range (KDa) }\end{array}$ & References \\
\hline Sephadex G-75 & $3-80$ & $\begin{array}{l}\text { Gildberg and Raa [48]; Wu et al. [52]; Zhou } \\
\text { et al. [60] }\end{array}$ \\
\hline SephadexG-100 & $4-150$ & $\begin{array}{l}\text { Pavlisko et al. [73]; Noda and Murakami [70]; } \\
\text { Bougatef et al. [50] }\end{array}$ \\
\hline Sephacryl S-200 & $5-250$ & $\begin{array}{l}\text { Nalinanon et al. [65]; Klomklao et al. [45]; } \\
\text { Tanji et al. [49]; Wu et al. [52]; Zhou et al. } \\
{[51]}\end{array}$ \\
\hline
\end{tabular}

Table 3: Molecular range for gel filtration matrix in fish PG purification.

released [108]. The flow rate must be carefully controlled to encourage the elution of one type of protein at a time $[48,50]$.

Gel filtration chromatography: Gel filtration chromatography (GFC) is used for further proteins purification based on different sizes of molecules [97,100]. Gel type is essential and each type corresponds to a distinct molecular size range. Sephadex G-75, Sephadex G-100 and Sephacryl S-200 can be used as gel matrices in the separation of different PGs (Table 3). As with ion-exchange chromatography, low flow rate gives a good resolution in gel filtration [109]. The flow rate is controlled within $10 \mathrm{ml} / \mathrm{h}, 20 \mathrm{ml} / \mathrm{h}$, and $30 \mathrm{ml} / \mathrm{h}$ for the gel media Sephacryl S-200 HR, Sephadex G-50 and Sephadex G-75, respectively. Long column length and small bead size will help to achieve good resolution but the capital cost is high and the process cannot be commercilized.

GFC has been successfully used for the purification of fish pepsinogens. El-Beltagy et al. [2] used a Sephadex G-100 gel filtration column with an acetate buffer at a flow rate of $20 \mathrm{ml} / \mathrm{h}$ to collect active PG fraction from bolti fish. Wu et al. [52] used Sephacryl S-200 HR and Sephadex G-75 columns with $25 \mathrm{mM}$ phosphate buffer (at flow rates of 0.6 and $0.4 \mathrm{ml} / \mathrm{min}$, respectively) to collect pure PGs from European eel. Nalinanon et al. [65] used Sephacryl S-200 HR and Sephadex G-50 columns with a sodium phosphate buffer at a flow rate of $0.5 \mathrm{ml} / \mathrm{min}$ to collect pure PG from albacore tuna.

\section{Aqueous two phase system (ATPS) purification of pepsinogen}

The ATPS method is applied for purification of fish pepsinogen. The formation of ATPS is based on two immiscible aqueous solutions, with a polymer and a salt dispersed in two phases individually [110112]. During the partition process, enzymes will be transferred in a large proportion towards the polymer-rich phase in the whole system. This occurs because of the strong protein-polymer interaction due to the highly hydrophobic groups of the protein surface exposed to the solvent [113]. The impurities (including soluble cells, blood, polysaccharides and pigments) are more hydrophilic and stay in the salt phase [110]. In this way, most of the enzymes can be isolated from other non-enzyme materials [111]. ATPS can yield an excellent environment which maintains the native structure of enzymes; it also allows purification by means of selective partitioning of the enzyme in one of the phases $[110,113,114]$. It is effective and easy to use for purification of proteins. The reagents used in this system can also be recycled, therefore reducing the cost [111]. ATPS is recognized as a promising and versatile technique for downstream processing of proteins [115].

Several researchers used ATPS for purification of proteases such as trypsin [112,116] á-chymotrypsin [117] and chymosin [111]. Klomklao et al. [116] used ATPS to purify trypsin from yellow fin tuna and found 15\% PEG1000 and 20\% $\mathrm{MgSO}_{4}$ as the best conditions for trypsin recovery (69\% yield). Rawdkuen et al. [118] purified proteases from Calotropisprocera latex and found that 18\% PEG 1000 and 14\% $\mathrm{MgSO}_{4}$ gavethe highest yield (75\%). However, only a few reports were found for pepsin recovery. Nalinanon et al. [110] prepared ATPS using several different polymer-salt combinations and found the optimum to be $25 \%$ PEG $1000-20 \% \mathrm{MgSO}_{4}$ for recovering pepsinogen from albacore tuna (a yield of 85.7\%). According to Nalinanon et al. [110], the storage properties of protease may change after the ATPS recovery (pepsinogen may not be affected but pepsin is subjected to reduced stablility). Therefore, further studies on the separation of protease from PEG and the storage stability after this step are needed.

\section{Activation of pepsinogen to pepsin}

In this step, purified PGs are suspended in acidic condition to completely convert them to pepsins by autolysis. The $\mathrm{pH}$ is adjusted to $2-3$ by adding $0.1 \mathrm{M} \mathrm{HCl}$ at a warm temperature $\left(25-35^{\circ} \mathrm{C}\right)$ to maintain good enzymatic activity [51]. Under such conditions the purified PGs are activated to pepsins. The mechanism of activation of pepsinogen to pepsin involves a series of complicated reactions. At its N-terminus, the zymogen pepsinogen contains a prosegment, an additional 44 amino acid sequence, which stabilizes the inactive form and prevents the combination of substrate and active site [119]. Under acidic pHs (below 5), the electrostatic interactions and peptide bonds between the prosegment and the active enzyme are disrupted and the prosegment conformation is transformed, leading to the ultimate removal of the prosegments from the active center and, therefore, forming the active form pepsin $[65,119,120]$. The newly created pepsin can proteolytically cleave the prosegment from additional pepsinogen, therefore creating more pepsin [120]. Depending on the type ofpepsinogen, the activation of pepsinogen proceeds in a direct pathway or a sequential pathway. In the direct pathway, pepsinogen is converted to pepsin directly, such as with PG III from North Pacific blue fin tuna [67] and PG from smooth hound [50]. In the sequential pathway, an intermediate form is involved, such as with PG from albacore tuna [65] PG II from North Pacific blue fin tuna [67] PG-I from sea bream [51] PG I and PG II from African coelacanth [49] PG-I and PG-II from Mandarin fish [60] and PG-I and PG-III from European eel [52]. The activation process lasts for 30-60 min after which the pure pepsin is obtained [65].

\section{Advantages and disadvantages of conventional and ATPS methods}

High homogeneity and purity of pepsin can be obtained by the conventional method $[49,50,52]$. Proper selection of chromatography can give a purification factor as high as 600 [65]. However, the conventional method usually has a low yield as more enzymes are lost during purification process. Also, the conventional methods are more ccomplicated, time-consuming and expensive.

The ATPS method has several advantages for pepsin recovery: (a) ATPS is readily and quick to prepare (b) pepsin can be obtained by low speed centrifugation (c) it yields an excellent environment for maintaining the native structure and stability of the enzymes, (d) due to existence in different aqueous phases, the polymers and salt can be readily recycled, (e) the scale-up process based on aqueous two phase systems are simple and (f) a continuous steady state is possible $[65,111,113,114]$. These merits as well as continuous operation, low capital cost, eco-friendly and good feasibility give ATPS great potential for industrial application. This method is recognized as a promising and versatile technique for downstream processing of proteins [115] 
The ATPS method cannot achieve as high purity as the conventional method; usually give a purification factor of less than 10. This method usually regarded as a primary purification method and other purification procedure should follow if higher purification factor is required [65].

\section{Assaying of Pepsin}

Protease assays include determination of: (a) enzyme activity, (b) enzyme concentration, (c) specific activity, (d) purification factor, (e) molecular weight, (f) homogeneity and (f) iso electric point (pI).

\section{Enzyme activity}

The most widely used method for pepsin activity (both crude and purified) was described by Anson and Mirsky (1932) and used by several researchers $[2,26,33,50,51,58,59,64]$. The principle is that pepsin proteolyzesacid-denatured hemoglobin (substrate) into the trichloro ethanoic acid (TCA) soluble hydrolysis products, mainly tyrosine and phenylalanine [121]. A buffer (such as glycine-HCland sodium acetate- $\mathrm{HCl}$ with a $\mathrm{pH}$ of 2.0-3.0) is added to the substrate-enzyme mixture and incubated for $10 \mathrm{~min}$ at $37^{\circ} \mathrm{C}$. TCA is added to terminate the enzymatic reaction and precipitate unhydrolyzed hemoglobins (incubation time of $5 \mathrm{~min}$ at $\left.37^{\circ} \mathrm{C}\right)$. Centrifugation $(6000 \mathrm{~g}-10,000 \mathrm{~g}$ for $10 \mathrm{~min}$ ) and filtration are used to separate the supernatant from the hydrolysis products. Absorbance of the clear filtrate is measured at $280 \mathrm{~nm}$ directly or at $578 \mathrm{~nm}$ after being complexed with Folin \& Ciocalteu's reagent. A blank is conducted in a similar way except that pepsin is added after the addition of TCA. Triplicate experiments are recommended for each sample determination [33].

Two types of units are used to determine total enzyme activity. One unit is defined as the amount of enzyme that produces an increase in absorbance (at $280 \mathrm{~nm}$ ) of 0.001 per minute at a temperature of $37^{\circ} \mathrm{C}$ and a pH of 2-3 [33]. Another unit is expressed as the amount of enzyme that liberates $1 \mu \mathrm{mol}$ tyrosine at a temperature of $37^{\circ} \mathrm{C}$ and a $\mathrm{pH}$ of 2-3, (absorbance at $578 \mathrm{~nm}$ ) developed by the hydrolysis products in complexion with the Folin \& Ciocalteu's reagent [122]. A standard curve of tyrosine is employed and tyrosine solutions with different concentrations ranging from $0-0.8 \mu \mathrm{mol}$ are prepared by diluting stock tyrosine solution $(1 \mathrm{mmol} / \mathrm{L})$ with distilled water. A fitted equation of the absorbance against molar concentration of tyrosineis used to determine the total enzyme activity.

\section{Enzyme concentration}

Protein concentrations, as a proxy of pepsin concentrations, can be measured with a variety of methods that determined protein, among which Lowry and Bradford methods are most widely used. The method described by Lowry et al. [123] is based on folin-phenolprotein complexion using bovine serum albumin (BSA) as a standard. Under alkaline condition, folin-phenol (phosphor-molybdicphosphotungstic) binds with proteins, resulting in a color change that increases the absorbance at $750 \mathrm{~nm}$. A standard curve is necessary and BSA is normally used as the standard. BSA solutions with different concentrations ranging from $0-600 \mu \mathrm{g} / \mathrm{ml}$ are prepared by diluting a stock BSA solution $(1 \mathrm{mg} / \mathrm{ml})$ with distilled water. A fitted equation of the absorbance against BSA concentration is used to determine the total enzyme concentration. A pepsin standard curve should be employed [2,48,52,63,69,73,82]. El-Beltagy et al. [2] used Lowry method to determine the enzyme concentration and extracted $216 \mathrm{mg}$ pepsin from Bolti fish.Wang et al. [82] used Lowry method and extract 26.3 mg pepsin from turbot. Xuet al. [69] used Lowry method and extracted
$22.2 \mathrm{mg}$ of pepsin I and $10.9 \mathrm{mg}$ of pepsin II from orange roughy. Amiza and OwusuApenten [63] used Lowry method and extracted $0.057 \mathrm{mg}$ purified pepsin from Atlantic cod. Noda and Murakami [70] used Lowry method and extracted $7.79 \mathrm{mg}$ of pepsin I and $7.2 \mathrm{mg}$ of pepsin II from sardine.

The method described by Bradford [124] is similar to the Lowry method except that it is based on the absorbance increase caused by the binding of Coomassie blue G-250dyeto proteins [125]. Standard curves are prepared in a similar way as in Lowry method except for substituting folin-phenol (dye) with Coomassie blue G-250 and would be most appropriately based on pepsin. Bradford method is faster, simpler and more sensitive than Lowry method [125]. However, it suffers from a higher detection limit. Bougatef et al. [50] used Bradford method and extracted $9.16 \mathrm{mg}$ of PG from smooth hound stomach after a series of chromatography steps. Castillo-Yáñez et al. [71] used Bradford method and extracted $0.1 \mathrm{mg} / \mathrm{ml}$ of pepsin from Monterey sardine.

\section{Specific activity (SA)}

The specific activity (SA) of recovered enzymes indicates the amount of enzyme activity per unit mass of protein and is an important measurement of enzyme quality and homogeneity [126]. Pure enzyme has a constant SA under the specific substrate concentration which is defined as follows [110]:

$$
\mathrm{SA}=\frac{\text { Protein activity }}{\text { Protein concentration }} \text { (units/mg protein) }
$$

The specific activity is affected by the purification factor, type of fish and type of enzyme [66]. As the purity of recovered enzymes increases, the specific activity is enhanced. Usually, more purifications yield higher specific activities. Bougatef et al. [50] obtained one type of PG from smooth hound and found its specific activity increased from $0.81 \mathrm{U} / \mathrm{mg}$ protein (crude enzyme) to $7.68 \mathrm{U} / \mathrm{mg}$ protein after the purifications. Squires et al. [61] reported specific activities of 3.4, 96.4 and $108.6 \mathrm{U} / \mathrm{mg}$ protein for pepsins I, II and III from Greenland cod, repectively. Tanji et al. [67] used ASF-GFC-IEC-GFC to purify PG I, PG II and PG III from North Pacific bluefin tuna and found that the specific activities were $18.2,41.5$ and $7.8 \mathrm{U} / \mathrm{mg}$ protein, respectively. These were higher than those of $12.6,12.8$ and $1.6 \mathrm{U} / \mathrm{mg}$ protein reported by Tanji et al. [49] for PGs from African coelacanth. Noda and Murakami [70] stated that after IEC purification pepin I from sardine had a specific activity of $53.6 \mathrm{U} / \mathrm{mg}$ proteins, which was higher than that of $40.24 \mathrm{U} / \mathrm{mg}$ protein of pepsin II. Wu et al. [52] found the potential SA of PG I from European eel to be $16.8 \mathrm{U} / \mathrm{mg}$ protein, which was lower than those of PG II and PG III (22.5 and $27.8 \mathrm{U} / \mathrm{mg}$ protein, respectively).

\section{Purification factor (PF)}

The purification factor (PF) of enzymes discribes the purity of the enzyme obtained after final purification compared with the crude extract and is defined as follows $[2,110]$ :

$$
\mathrm{PF}=\frac{S A_{p}}{S A_{c}}
$$

Where: $\mathrm{SA}_{\mathrm{p}}$ is the SA of purified protease

$\mathrm{SA}_{c}$ is the SA of crude extract or acidified extract

The PF may vary due to various experimental conditions. Zhou et al. [51] purified four types of pepsinogens (PG I, PG II, PG III and PG IV) 
by ASF and two chromatographic steps and found their PFs to be 9.9, 9.9, 9.9 and 9.6, respectively. Simlar results were reported by Wang et al. [82], Bougatef et al. [50] and Castillo-Yáñez et al. [71]. Gildberg and Raa [48] used comparable steps and obtained much purer pepsins I and II from Arctic capelin with the PFs of 42.6 and 76.9, respectively. Xuet al. [69] used ASF and three chromatographic steps to purify pepsins I and II from the stomach of orange roughy and obtained PFs of 74.3 and 76.1, respectively. Usually, increased purifications give higher purity. However, as the protease become purer, its yield is usually lowered.

\section{Molecular weight}

The molecular weight of the purified enzymes can be evaluated by the sodium dodecyl sulphate-polyacrylamide gel electrophoresis (SDS-PAGE). SDS-PAGE uses a detergent, sodium dodecyl sulfate (SDS), to denature the proteins and provide a negative charge that is proportional to the molecular weight, allowing electrophoretic separation of different protein molecules. Therefore, molecular weights of pepsin and pepsinogen can be estimated by comparisons with a series of proteins with known molecular weights. Bougatef et al.[50] found the molecular weight of one type of PG and its corresponding pepsin from smooth hound to be 40 and $35 \mathrm{kDa}$, respectively. Tanji et al. [49] used SDS-PAGE to determine the molecular weights of three PGs from African coelacanth and reported $37.0 \mathrm{kDa}$ for PG I and PG II and $39.3 \mathrm{kDa}$ for PG III. Zhou et al. [60] used a similar method for molecular weight determination and obtained 36,35 , 38and $35 \mathrm{kDa}$ for four purified PGs and 31, 30, 32 and $30 \mathrm{kDa}$ for the four corresponding pepsins from mandarin fish, respectively. These results were similar to those reported for European eel [52], sea bream [51] and pectoral rattail [45].

\section{Homogeneity}

Native polyacryl amide gel electrophoresis (native PAGE) is often performed for analysis of homogeneity of the enzymes, which is different from SDS-PAGE. Native PAGE separates proteins according to their mass-charge ratio while in SDS-PAGE, SDS denatures and binds to the protein which is separated primarily by mass [127]. Native PAGE is not a good measurement of molecular weight as SDS-PAGE but can determine the protein charge or subunit composition.Therefore, the analyzed enzymes (maintaining their natural conformation and homogeneity) can be determined. Klomklao et al. [45] used native PAGE and found that pepsins I and II purified from pectoral rattailexhibited single band which indicated the purified enzymes were homogeneous. El-Beltagy et al. [2] used a similar method and stated that the PAGE pattern of the pepsin eluted by column chromatography revealed only one band, which proved that the enzyme was quite homogenous. Several researchers $[49,57,65,67]$ used this method and found the final enzymes were pure and homogenous.

\section{Isoelectric point $(\mathrm{pI})$}

The isoelectric point ( $\mathrm{pI}$ ) of fish pepsin is the $\mathrm{pH}$ at which the enzyme molecule or surface carries no net electrical charge. The isoelectric point of pepsin is usually evaluated by analytical electro focusing in thin layer polyacrylamide flat gel (ampholyne polyacrylamide gel plate) containing ampholyne over a $\mathrm{pH}$ range of 3.5-9.5, with a calibration kit containing many proteins of known isoelectric points as a reference [46,71]. After separation, the proteins are stained with coomassie brilliant blue and their $\mathrm{pI}$ can be evaluated by comparison to reference proteins. The isoelectric points of fish pepsins, which have been determined by several researchers by the same approach range from 4.0 to 6.5. Castillo-Yáñez et al. [71] found that the isoelectric points for two types of pepsin isolated from Monterey sardine were 4.0 and 4.5. Gildberg and Raa [48] used an analytical eletrofocusing method to analyze the $\mathrm{pI}$ of pepsins and reported pIs of 6.6 and 3.5 for pepsins I and II from Arctic capelin, respectively. Bjelland et al. [64] found that pIs for pepsins I and II from Atlantic cod were 6.9 and 4.2, respectively. Xuet al. [69] found the pIs for pepsins I and II ( $a$ and $b$ ) from orange roughy were $5.5,4.35$ and 4.4 , respectively.

\section{Kinetics of Fish Pepsin}

\section{Catalytic reaction}

When enzymes interact with specific substrates, the catalytic reaction can be described as follows [38]:

$$
\mathrm{E}+\mathrm{S} \underset{k_{-1}}{\stackrel{k_{1}}{\rightleftarrows}} E S \stackrel{k_{7}}{\longrightarrow} E+P
$$

Where:

\section{$\mathrm{E}$ is the enzyme}

$\mathrm{S}$ is the substrate

ES is the enzyme-substrate complex

$\mathrm{P}$ is the product produced.

$\mathrm{k}_{1}$ is the forward rate constant for substrate binding

$\mathrm{k}_{-1}$ is the reverse rate constant for substrate binding

$\mathrm{k}_{2}$ is the catalytic rate constant (containing terms related to the transition state)

This reaction can be expressed by the Michaelis-Menten equation as follows:

$V_{0}=\frac{V_{\max }[S]}{K_{m}+[S]}$

Where:

$\mathrm{V}_{0}$ is the initial reaction rate

$[S]$ is the substrate concentration at this time

$\mathrm{V}_{\max }$ isthe maximum reaction rate under a specific experimental condition

$\mathrm{K}_{\mathrm{m}}$ is Michaelis-Menten constant and refers to the substrate concentration at $1 / 2$ maximum reaction rate

$\mathrm{K}_{\mathrm{m}}$ can be determined by the profile of the reaction velocity at different substrate concentrations. By modifying the MichaelisMenten equation, a linear format called Lineweaver-Burk equation is obtained [128].

$\frac{1}{V_{0}}=\frac{K_{m}+[S]}{V_{\max }[S]}$

or

$\frac{1}{V_{0}}=\frac{1}{V_{\max }}+\frac{K_{m}}{V_{\max }} \cdot \frac{1}{[\mathrm{~S}]}$

By plotting $1 /[\mathrm{S}]$ versus $1 / \mathrm{V}_{0}$, the slope $\left(\mathrm{K}_{\mathrm{m}} / \mathrm{V}_{\max }\right)$ and intercept $\left(1 / \mathrm{V}_{\max }\right)$ can be obtained and $\mathrm{K}_{\mathrm{m}}$ can be calculated. $\mathrm{k}_{\text {cat }}$ is the turnover number, which refers to the number of substrate molecules converted to product molecules by one enzyme molecule per unit time. $\mathrm{k}_{\text {cat }}$ can be obtained by the following equation: 


\begin{tabular}{|l|l|l|l|l|}
\hline Enzyme & $\begin{array}{l}\text { Identified } \\
\text { Species }\end{array}$ & $\mathbf{K}_{\mathbf{m}}(\mathbf{m M})$ & $\mathbf{k}_{\text {cat }}\left(\mathbf{S}^{-1}\right)$ & Reference \\
\hline Pepsin & Bolti fish & 0.77 & - & El-Beltagy et al.[2] \\
\hline Pepsin & Polar cod & 1.33 & - & Arunchalam and Haard [76] \\
\hline Pepsin I & Pectoral rattail & 0.098 & 50 & Klomklao et al. [45] \\
\hline Pepsin II & Pectoral rattail & 0.152 & 32 & Klomklao et al. [45] \\
\hline Pepsin I & European eel & 0.088 & 23.7 & Wu et al. [52] \\
\hline Pepsin II & European eel & 0.092 & 19.4 & Wu et al. [52] \\
\hline Pepsin III & European eel & 0.07 & 34.4 & Wu et al. [52] \\
\hline Pepsin I & Sea bream & 0.087 & - & Zhou et al. [51] \\
\hline Pepsin II & Sea bream & 0.1 & - & Zhou et al. [51] \\
\hline Pepsin III & Sea bream & 0.086 & - & Zhou et al. [51] \\
\hline Pepsin IV & Sea bream & 0.073 & - & Zhou et al. [51] \\
\hline Pepsin I & Atlantic cod & 0.156 & 18 & Gildberg et al. [46] \\
\hline Pepsin II & Atlantic cod & 0.044 & 33 & Gildberg et al.[46] \\
\hline Pepsin I & Antarctic fish & 0.074 & 3.32 & De Luca et al. [38] \\
\hline Pepsin II & Antarctic fish & 0.025 & 0.54 & De Luca et al.[38] \\
\hline
\end{tabular}

Table 4: $\mathrm{K}_{\mathrm{m}}$ and $\mathrm{k}_{\mathrm{cat}}$ of pepsins from different fish species.

$$
k_{\text {cat }}=\frac{V_{\max }}{[E]}
$$

Where:

$[E]$ is the enzyme concentration.

Zhou et al. [51] found the $\mathrm{K}_{\mathrm{m}}$ values for pepsins I, II, III and IV from sea bream to be $8.7 \times 10^{-8}, 1.0 \times 10^{-7}, 8.6 \times 10^{-8}$ and $7.3 \times 10^{-8} \mathrm{M}$, respectively. Two pepsins from Antarctic fish were found to have lower values of $\mathrm{K}_{\mathrm{m}}(0.074 \mathrm{mM}$ and $0.025 \mathrm{mM})$ and $\mathrm{k}_{\text {cat }}\left(3.32 \mathrm{~S}^{-1}\right.$ and $\left.0.54 \mathrm{~S}^{-1}\right)$ than those $\left(\mathrm{K}_{\mathrm{m}}=0.26 \mathrm{mM}\right.$ and $\left.\mathrm{k}_{\text {cat }}=72.02 \mathrm{~S}^{-1}\right)$ from pig pepsin [38]. Klomklao et al. [45] found the $\mathrm{K}_{\mathrm{m}}$ values of two pepsins from pectoral rat tail were 0.098 and $0.152 \mathrm{mM}$ and $\mathrm{k}_{\text {cat }}$ values were 50 and $32 \mathrm{~S}^{-1}$. Pepsin from polar cod exhibited a higher $\mathrm{K}_{\mathrm{m}}$ than those obtained from warm water fishes $[30,46,64,74,76]$. A summary of $K_{m}$ and $k_{c a t}$ values for different pepsins is shown in Table 4.

\section{Partition coefficient $\left(K_{\mathrm{p}}\right)$}

The partition coefficient $\left(\mathrm{K}_{\mathrm{p}}\right)$ of recovered proteases is used to characterize the protein distribution in ATPS and is defined as follows [110]:

$$
k_{p}=\frac{C_{T}}{C_{B}}
$$

Where:

$\mathrm{C}_{\mathrm{T}}$ is the concentration of protein in top phase

$\mathrm{C}_{\mathrm{B}}$ is the concentration of protein in bottom phase

Generally, a low partition coefficient indicates transfer of more proteins, nucleic acids and other contaminants to the bottom phase $[116,118]$. The phase system composition (salt type and concentration and PEG molecular weight and concentration) can influence the partition of phase components and therefore have a significant influence on $\mathrm{K}_{\mathrm{p}}$ [110]. Klomklao et al. [116] investigated partition coefficients during spleen proteinase isolation and found that $20 \%$ PEG1000-20\% $\mathrm{MgSO}_{4}$ yielded a low $\mathrm{K}_{\mathrm{p}}$ of 0.32 (less impurity) while $20 \%$ PEG $1000-20 \%\left(\mathrm{NH}_{4}\right)_{2} \mathrm{SO}_{4}$ gave a high value (1.73). Rawdkuen et al. [118] used a similar method for protease recovery from the latex of Calotropisprocera and found the phase combination 18\% PEG 1000$20 \% \mathrm{MgSO}_{4}$ had the lowest $\mathrm{K}_{\mathrm{p}}(0.03)$ while $18 \% \mathrm{PEG} 1000-20 \% \mathrm{~K}_{2} \mathrm{HPO}_{4}$ had the highest value (4.0). However, $\mathrm{K}_{\mathrm{p}}$ only indicates the movement of protein mixture (including target enzymes and undesirable proteins) instead of a single enzyme. Usually, good partition results from a moderate $\mathrm{K}_{\mathrm{p}}$ (highest or lowest values cannot give good partitioning).

\section{Volume ratio $\left(\mathrm{V}_{\mathrm{R}}\right)$}

The Volume Ratio $\left(\mathrm{V}_{\mathrm{R}}\right)$ of recovered proteases shows the phase volume distribution in ATPS and is defined as follows [110].

$$
V_{R}=\frac{V_{T}}{V_{B}}
$$

Where:

$\mathrm{V}_{\mathrm{T}}$ is the volume of solution in the top phase

$\mathrm{V}_{\mathrm{B}}$ is the volume of solution in the bottom phase

Nalinanon et al. [110], Chaiwut et al. [129] and Rawdkuen et al. [118] reported that the $V_{R}$ decreased when salt concentration increased. Increasing salt concentration from $11 \%$ to $17 \%$ gave a higher proportion of salt-rich bottom phase, therefore, resulting in decrease in $V_{R}$ [129]. Nalinanon et al. [110] investigated the pepsin partition from albacore tuna and reported that, with the same polymer $(20 \%$ PEG 1000), $\mathrm{V}_{\mathrm{R}}$ decreased from 0.91 to 0.59 as $\mathrm{K}_{2} \mathrm{HPO}_{4}$ increased from $15 \%$ to $25 \%$. Chaiwut et al. [129] reported that when the concentration of $\left(\mathrm{NH}_{4}\right)_{2} \mathrm{SO}_{4}$ increased from $14 \%$ to $17 \%$ with the fixed polymer (12\% PEG 4000), $V_{R}$ was reduced from 1.17 to 0.42 during protease extraction from Calotropisprocera latex.

\section{Recovery yield}

The recovery yield of protease is a characteristic parameter showing recovery efficiency. It is calculated from the ratio of protease activities in ATPS and defined as follows [110]:

$$
\text { Yield }(\%)=\frac{A_{t}}{A_{i}} \times 100
$$

Where:

\section{$A_{t}$ is enzyme activity of purified protease}

$A_{i}$ is the enzyme activity of crude extract or acidified extract.

High values of recovery yield indicates that more desired enzymes were partitioned from the original material and experimental conditions gave an effective recovery. Squires et al. [61] used a conventional purification method (ASF, ultrifiltration and a series of chromatographic steps) to extract pepsins from Greenland cod and found the yields of pepsins I, II and III were $4.4 \%, 14.3 \%$ and $13.0 \%$, respectively. These results were similar to those for Arctic capelin reported by Gildberg and Raa [48] and for mandarin fish reported by Zhou et al. [60]. Noda and Murakami [70] purified pepsins I and II from sardine and found lower yields $(3.4 \%$ and $1.9 \%$ for pepsins I and II, respectively).Similar results were reported by $\mathrm{Wu}$ et al. [52] and Twining et al. [57]. As the number of purification steps increased, enzyme yield will be greatly reduced. 


\section{Conclusion}

Pepsin is an important aspartic proteases existing in the fish stomach. Its enzymatic activity can be affected by three factors: $\mathrm{pH}$, temperature and inhibitor. Each type of fish pepsin has a distinct optimum $\mathrm{pH}, \mathrm{pH}$ stability, an optimum temperature and temperature stability. Warm water fish pepsins have a higher optimum temperature and a higher upper temperature limit of $40-50^{\circ} \mathrm{C}$ while cold water fish pepsins are quite susceptible to higher temperatures. Pepstatin A with a specific molar pepstatin topepsin ratio and sodium dodecyl sulfate (SDS) at $0.05-0.10 \%(\mathrm{w} / \mathrm{v})$ have strong inhibitory effects on pepsin activity while PMSF, E-64 and EDTA have a negligible impact on pepsin activity. Cysteine and aliphatic alcohols, have been identified as effective inhibitors while ATP, molybdate, $\mathrm{NaCl}, \mathrm{MgCl}_{2}$, and $\mathrm{CaCl}_{2}$ are not. Pepsin is used in collagen extraction, in medical research, as a rennet substitute, in the production of fish silage and in digestibility therapy. Pepsins are partition edusing a four step procedure including preparation of the fish stomach, extraction of crude PG, purification of PG and activation of $\mathrm{PG}$ to pepsin at an acidic $\mathrm{pH}$. The purification of PG is achieved by the conventional method and aqueous two phase system (ATPS). The conventional method is used for highly purified pepsin and involves ammonium sulfate fractionation, gel filtration or anion exchange chromatography. ATPS is used for partially purified pepsin and is based on two immiscible aqueous polymersalt solutions. The innovative methods for pepsin partition have been proposed but large scale of pepsin recovery is still in demand in the industry at present. The characteristics of fish pepsin are assayed by enzyme activity and concentration, specific activity (SA), purification factor (PF), molecular weight, homogeneity and isoelectric point (pI). Pepsin is considered a promising protease with wide applications in both conventional and new industries and new efficient, cost effective techniques for its recovery and purification should be developed.

\section{Acknowledgement}

This research was supported by the Natural Sciences and Engineering Research Council (NSERC) of Canada.

\section{References}

1. Gildberg A, Raa J (1998) Properties of a propionic acid/formic acid preserved silage of cod viscera. J Sci Food Agric 28: 647-653.

2. El-Beltagy AE, El-Adawy TA, Rahma EH, El-Bedawey AA (2004) Purification and characterization of an acidic protease from the viscera of bolti fish (Tilapia nilotica). Food Chem 86: 33-39.

3. Nagai T, Suzuki N (2000) Isolation of collagen from fish waste material - skin, bone and fins. Food Chem 68: 277-281.

4. Ogawa M, Portier RJ, Moody MW, Bell J, Schexnayder MA, et al. (2004) Biochemical properties of bone and scale collagens isolated from the subtropical fish black drum (Pogoniscromis) and sheepsheadseabream (Archosargusprobatocephalus). Food Chem 88: 495-501.

5. Yoshida H, Terashima M, Takahashi Y (1999) Production of organic acids and amino acids from fish meat by sub-critical water hydrolysis. Biotechnol Prog 15: $1090-1094$

6. Genicot S, Rentier-Delrue F, Edward D, VanBeeumen J, Gerday C (1996) Trypsin and trypsinogen from an Antarctic fish: molecular basis of cold adaption. Biochim Biophys Acta 1298: 45-57.

7. Klomklao S, Benjakul S, Visessanguan W, Kishimura H, Simpson BK (2006) Purification and characterization of trypsin from the spleen of tongol tuna (Thunnustonggol). J Agric Food Chem 54: 5617-5622.

8. Castillo-Yáñez FJ, Pacheco-Aguilar R, García-Carreño FL, Navarretedel Toro MA, López MF (2006) Purification and biochemical characterization of chymotrypsin from the viscera of monterey sardine (Sardinops sagax caeruleus). Food Chem 99: 252-259.

9. Gildberg A, Øverbø K (1990) Purification and characterization of pancreatic elastase from Atlantic cod (Gadus morhua). Comp Biochem Physiol B 97: 775782.

10. Wiggers VR, Wisniewski Jr A, Madureira LAS, Chivanga Barros AA, Meier HF (2009) Biofuels from waste fish oil pyrolysis: Continuous production in a pilot plant. Fuel 88: 2135-2141.

11. Jongjareonrak A, Benjakul S, Visessanguan W, Nagai T, Tanaka M (2005) Isolation and characterisation of acid and pepsin-solubilised collagens from the skin of brownstripe red snapper (Lutjanus vitta). Food Chem 93: 475-484.

12. Zhang Y, Liu W, Li G, Shi B, Miao Y, et al. (2007) Isolation and partial characterization of pepsin-soluble collagen from the skin of grass carp (Ctenopharyngodon idella). Food Chem 103: 906-912.

13. Nalinanon S, Benjakul S, Visessanguan W, Kishimura $H$ (2007) Use of pepsin for collagen extraction from the skin of bigeye snapper (Priacanthustayenus). Food Chem104: 593-601.

14. Nalinanon S, Benjakul S, Visessanguan W, Kishimura H (2008) Improvement of gelatin extraction from bigeye snapper skin using pepsin-aided process in combination with protease inhibitor. Food Hydrocolloids 22: 615-622.

15. Aehle W (2007) Enzymes in industry: production and applications. (3rdedn) Wiley-VCH, Weinheim, Germany, 136-137.

16. Thorne Research (2010) Betaine $\mathrm{HCl}$ and Pepsin; Dover, USA. Sogawa $\mathrm{K}$ Fujii-Kuriyama Y, Mizukami Y, Ichihara Y, Takahashi T (1983) Primary structure of human pepsinogen gene. J Biol Chem 258: 5306-5311.

17. Sogawa K, Fujii-Kuriyama Y, Mizukami Y, Ichihara Y, Takahashi T (1983) Primary structure of human pepsinogen gene. J Biol Chem 258: 5306-5311

18. Kageyama T, Takahashi K (1976) Pepsinogens and pepsins from gastric mucosa of Japanese monkey. Purification and characterization. J Biochem 79: 455-468.

19. Nielsen PK, Foltmann B (1995) Purification and characterization of porcine pepsinogen B and pepsin B. Arch Biochem Biophys 322 : 417-422.

20. Martin P, Torieu-Cuot P, Collin JC, Ribadeau Dumas B (1982) Purification and characterization of bovine gastricsin. Eur J Biochem 122: 31-39

21. Suzuki M, Narita Y, Oda S, Moriyama A, Takenaka O, et al. (1999) Purification and characterization of goat pepsinogens and pepsins. Comp Biochem Physiol B Biochem Mol Biol 122: 453-460.

22. Muto N, Tani S (1979) Purification and characterization of rat pepsinogens whose contents increase with developmental progress. J Biochem 85: 11431149.

23. Kageyama T, Tanabe K, Koiwai O (1990) Structure and development of rabbit pepsinogens. Stage-specific zymogens, nucleotide sequences of cDNAs, molecular evolution, and gene expression during development. J Biol Chem 265: 17031-17038.

24. Gildberg A (1992) Recovery of proteinases and protein hydrolysates from fish viscera. Bioresource Technol 39: 271-276.

25. Simpson BK (2000) Digestive proteinases from marine animals. In Seafood enzymes: utilization and influence on postharvest seafood quality. Haard HF Simpson BK, Eds. Marcel Dekker, Inc: New York, 191-213.

26. Fruton JS (1971) Hydrolysis: peptide bonds, (3rd edn), Academic Press Inc: New York 3: 120-152.

27. Effront J, Prescott SC, Venable CS (2007) Biochemical catalysts in life and industry: proteolytic enzymes. Kessinger Publishing: 151-289.

28. Bobe J, Goetz FW (2001) An ovarian progastricsin is present in the trout coelomic fluid after ovulation. Biol Reprod 64: 1048-1055.

29. Kurokawa T, Uji S, Suzuki T (2005) Identification of pepsinogen gene in the genome of stomachless fish, Takifugu rubripes. Comp Biochem Physiol B Biochem Mol Biol 40: 133-140. 
30. Shahidi F, Janak Kamil YVA (2001) Enzymes from fish and aquatic invertebrates and their application in the food industry. Trends Food Sci Technol 12: 435

31. Raufman J (2004) Pepsin. In Encyclopedia of Gastroenterology, Johnson L R Ed., Academic Press, Amsterdam 3: 147-148.

32. Karlsen S, Hough E, Olsen RL (1998) Structure and proposed amino-acid sequence of a pepsin from Atlantic cod (Gadus morhua). Acta Crystallogr D Biol Crystallogr 54: 32-46.

33. Andreeva NS, Rumsh LD (2001) Analysis of crystal structures of aspartic proteinases: On the role of amino acid residues adjacent to the catalytic site of pepsin-like enzymes. Protein Sci 10: 2439-2450.

34. Worthington V (2010) Worthington enzyme manual: enzymes and related biochemicals; Worthington Biochemical Corporation, U.S.A.

35. Suguna K, Padlan EA, Smith KW, Carlson WD, Davies DR (1987) Binding of a reduced peptide inhibitor to the aspartic proteinase from Rhizopus chinensis: Implications for a mechanism of action. ProcNatlAcadSci U S A 84: 7009-7013.

36. Davies DR (1990) The Structure and Function of the Aspartic Proteinases. Annu Rev Biophys Chem 19: 189-215.

37. Benjakul S, Klomklao S, Simpson BK (2010) Enzymes in fish processing. In Enzymes in Food Technology (2ndedn), Whitehurst RJ, Van Oort M, Eds. Blackwell Publishing, Chichester: 211-225.

38. De Luca V, Maria G, De Mauro G, Catara G, Carginale V, et al. (2009) Aspartic proteinases in Antarctic fish. Mar Genomics 2: 1-10.

39. Polgár $L$ (1987) The mechanism of action of aspartic proteases involves "pushpull" catalysis. FEBS Lett 219: 1-4.

40. Deng Y, Zhao J, Lu G, Wu X, Tao Y (2010) Cloning, characterization and expression of the pepsinogen $\mathrm{C}$ from the golden mandarin fish Sinipercascherzeri (Teleostei: Perciformes). Fish Sci 76: 819-826.

41. Foltmann B (1981) Gastric proteinases-structure, function, evolution and mechanism of action. Essays Biochem 17: 52-84

42. Cooper JB, Khan G, Taylor G, Tickle IJ, Blundell TL (1990) X-ray analyses of aspartic proteinases. II. Three-dimensional structure of the hexagonal crystal form of porcine pepsin at 2.3 A resolution. J Mol Biol 214: 199-222.

43. Kageyama T (2002) Pepsinogen, progastricsin, and prochymosin: structure function, evolution, and development. Cell Mol Life Sci 59: 288-306.

44. Tanji M, Yakabe E, Kubota K, Kageyama T, Ichinose M, et al. (2009) Structura and phylogenetic comparison of three pepsinogens from Pacific bluefin tuna: molecular evolution of fish pepsinogens. Comp Biochem Physiol B Biochem Mol Biol 152: 9-19.

45. Klomklao S, Kishimura H, Yabe M, Benjakul S (2007) Purification and characterization of two pepsins from the stomach of pectoral rattail (coryphaenoidespectoralis). Comp Biochem Physiol B Biochem Mol Biol 147: 682-689.

46. Gildberg A, Olsen RL, Bjarnason JB (1990) Catalytic properties and chemica composition of pepsins from Atlantic cod (Gadusmorhua). Comp Biochem Physiol B 96: 323-330.

47. Feng S, Li W, Lin H (2008) Characterization and expression of the pepsinogen $\mathrm{C}$ gene and determination of pepsin-like enzyme activity from orange-spotted grouper (Epinephelus coioides). Comp Biochem Physiol B149: 275-284.

48. Gildberg A, Raa J (1983) Purification and characterization of pepsins from the arctic fish capelin (Mallotus villosus). Comp Biochem Physiol A Comp Physio 75: $337-342$.

49. Tanji M, Yakabe E, Kageyama T, Yokobori S, Ichinose M, et al. (2007) Purification and characterization of pepsinogens from the gastric mucosa of African coelacanth, Latimeria chalumnae, and properties of the major pepsins. Comp Biochem Physiol B Biochem Mol Biol 146: 412-420.

50. Bougatef A, Balti R, Zaied SB, Souissi N, Nasri M (2008) Pepsinogen and pepsin from the stomach of smooth hound (Mustelus mustelus): Purification, characterization and amino acid terminal sequences. Food Chem 107: $777-$ 784
51. Zhou Q, Fu X, Zhang L, Su W, Cao M Purification and characterization of sea bream (Sparus latus Houttuyn) pepsinogens and pepsins. Food Chem 103 $795-801$

52. Wu T, Sun L, Du C, Cai Q, Zhang Q, et al. (2009) Identification of pepsinogens and pepsins from the stomach of European eel (Anguilla anguilla). Food Chem 115: $137-142$

53. Gildberg A (2004) Enzymes and bioactive peptides from fish waste related to fish silage, fish feed and fish sauce production. J Aquat Food Prod Technol 13 3-11.

54. Haard NF (1992) Control of chemical composition and food quality attributes of cultured fish. Food Res Int 25: 289-307.

55. García-Carreño FL, Hernández-Cortés MP, Haard NF (1994) Enzymes with peptidase and proteinase activity from the digestive systems of a freshwate and a marine decapod. J Agric Food Chem 42: 1456-1461.

56. Gildberg A (1998) Aspartic proteinases in fishes and aquatic invertebrates Comp Biochem Physiol B 91: 425-435.

57. Twining SS, Alexander PA, Huibregtse K, Glick DM (1983) A pepsinogen from rainbow trout. Comp Biochem Physiol B 75: 109-112.

58. Gildberg A (2004) Digestive enzyme activities in starved pre-slaughter farmed and wild-captured, Atlantic cod (Gadus morhua). Aquaculture 238: 343-353.

59. Brier S, Maria G, Carginale V, Capasso A, Wu Y, et al. (2007) Purification and characterization of pepsins $\mathrm{A} 1$ and $\mathrm{A} 2$ from the Antarctic rock cod Trematomusbernacchii. FEBS J 274: 6152-6166.

60. Zhou Q, Liu G, Huang Y, Weng L, Hara K, et al. (2008) Pepsinogens and pepsins from mandarin fish (sinipercachuatsi). J Agric Food Chem 56: 5401 5406.

61. Squires EJ, Haard NF, Feltham LA (1986) Gastric proteases of the Greenland cod Gadus ogac. I. Isolation and kinetic properties. Biochem Cell Biol 64: 205 214

62. Haard NF (1986) Atlantic Cod Gastric Protease. Characterization with casein and milk substrate and influence of sepharose immobilization on salt activation, temperature characteristics and milk clotting reaction. J Food Sci 51: 313-316.

63. Amiza MA, Owusu Apenten RK (2002) A single step purification of gastricsinlike proteinase from Atlantic cod (Gadus morhua). OnLine J Biol Sci 2: 591-595.

64. Bjelland S, Gildberg A, Volden G (1988) Degradation of human epidermal keratin by fish pepsin. Arch Dermatol Res 280: 119-123.

65. Nalinanon S, Benjakul S, Kishimura H (2010) Biochemical properties of pepsinogen and pepsin from the stomach of albacore tuna (Thunnus alalunga) Food Chem 121: 49-55.

66. Nalinanon S, Benjakul S, Visessanguan W, Kishimura H (2008) Tuna pepsin: characteristics and its use for collagen extraction from the skin of threadfin bream (Nemipterus spp.). J Food Sci 73: C413-419.

67. Tanji M, Kageyama T, Takahashi K (1988) Tuna pepsinogens and pepsins Purification, characterization and amino-terminal sequence. Eur $\mathrm{J}$ Biochem 177: 251-259.

68. Norris ER, Mathies JC (1953) Preparation, properties, and crystallization of tuna pepsin. J BiolChem 204: 673-680.

69. Xu RA, Wong RJ, Rogers ML, Fletcher GC (1996) Purification and characterization of acidic proteases from the stomach of the deepwater finfish orange roughy (Hoplostethus atlanticus). J Food Biochem 20: 31-48.

70. Noda M, Murakami K (1981) Studies on proteinases from the digestive organ of sardine. II. purification and characterization of two acid proteinases from the stomach. Biochim Biophys Acta 658: 27-34.

71. Castillo-Yáñez FJ, Pacheco-Aguilar R, Garcia-Carreño FL, Navarrete-de Toro MA (2004) Characterization of acidic proteolytic enzymes from monterey sardine (sardinops sagax caerulea) viscera. Food Chem 85: 343-350

72. Haard NF, ShamsuzzamanK, Brewer P, Arnchalam K (1982) Enzymes from marine organisms as rennet substitutes. In Use of enzymes in food technology. Symposium International Versailles, Dupuy P, Ed., Technique et Documentation Lavoisier, Paris, 237-241. 
73. Pavlisko A, Rial A, Devecchi S, Coppes Z (1997) Properties of pepsin and trypsin isolated from the digestive tract of parona signata "Palometa". J Food Biochem 21: 289-308.

74. Simpson BK, Haard NF (1987) Cold-adapted enzymes from fish. In Food Biotechnology, Knorr DW, Ed, Marcel Dekker Inc, New York, 495-527.

75. Guerard F, Le Gal Y (1987) Characterization of a chymosin-like pepsin from the dogfish Scyliorhinus canicula. Comp Biochem Physiol B 88: 823-827.

76. Arunchalam K, Haard NF (1985) Isolation and characterization of pepsin from polar cod (Boreogadus saida). Comp Biochem Physiol B 80: 467-473.

77. Copeland RA (2005) Evaluation of enzyme inhibitors in drug discovery: A guide for medicinal chemists and pharmacologists. John Wiely and Sons Inc, Hoboken, New Jersey, 34-66.

78. Umezawa H, Aoyagi T, Morishima H, Matsuzaki M, Hamada M (1970) Pepstatin, a new pepsin inhibitor produced by agtinomygetes. J Antibiot (Tokyo) 23: 259262.

79. Zollner H (1999) Handbook of enzyme inhibitors. (3thedn), Wiley-VCH, Chichester, UK, 440-445

80. Yakabe E, Tanji M, Ichinose M, Goto S, Miki K, et al. (1991) Purification characterization, and amino acid sequences of pepsinogens and pepsins from the esophageal mucosa of bullfrog (Rana catesbeiana). J Biol Chem 266: 22436-22443.

81. Tang J (1965) Competitive inhibition of pepsin by aliphatic alcohols. J Biol Chem 240: 3810-3815

82. Wang $H$, Wang $Y$, Wang $Q$, Xue C, Sun M (2006) Purification and characterization of stomach protease from the turbot (Scophthalmus maximus L.) Fish Physiol Bio chem 32: 179-188.

83. Nagai T, Yamashita E, Taniguchi K, Kanamori N, Suzuki N (2001) Isolation and characterisation of collagen from the outer skin waste material of cuttlefish (Sepia lycidas). Food Chem 72: 425-429.

84. Ahmad M, Benjakul S (2010) Extraction and characterisation of pepsinsolubilised collagen from the skin of unicorn leatherjacket (Aluterus monocerous). Food Chem120: 817-824.

85. Gorgas FJS (2009) Dental medicine. A manual of dental material medica and therapeutics, Nabu Press, Washington, 48-50.

86. Murado MA, González MDP, Vázquez JA (2009) Recovery of proteolytic and collagenolytic activities from viscera by-products of rayfish (Raja clavata). Mar Drugs 7: 803-815.

87. Almås KA (1990) Utilization of marine biomass for production of microbial growth media and biochemicals. In Advances in Fisheries Technology and Biotechnology for increased profitability, Voigt MN, Botta JR, Eds., Technomic Publishing Company, Lamcaster, 361-372.

88. Brewer P, Helbig N, Haard NF (1984) Atlantic cod pepsin. Characterization and use as a rennet substitute. Can Inst Food Sci Technol 17: 38-43.

89. Tavares JFP, Baptista JAB, Marcone MF (1997) Milk-coagulating enzymes of tuna fish waste as a rennet substitute. Int J Food Sci Nutr 48: 169-176.

90. Raa J, Gildberg A (1982) Fish silage: A review. Crit Rev Food Sci Nutr 16: 383419

91. Gildberg A, Almås KA (1986) Utilization of fish viscera. In Food Engineering and Process Application, LeMaguer M, Jelen P, Eds, Elsevier Applied Science Publishers, London, 383-393.

92. Raa J, Gildberg A (1976) Autolysis and proteolytic activity of cod viscera. Int J Food Sci Technol 11: 619-628.

93. Windsor M, Barlow S (1981) Introduction to fishery by-products. Fishing News Books, Farnham, UK, 153-154.

94. Goddard JS, Al-Yahyai DSS (2001) Chemical and nutritional characteristics of dried sardine silage. J Aquat Food Prod Technol 10: 39-50.

95. Saisithi P (1994) Traditional fermented fish: Fish sauce production. In Fisheries Processing: Biotechnological Applications, Martin AM, Eds, Chapman and Hall, London, 111-131.
96. Joakimsson KG (1984) Enzymatic deskinning of herring (Clupea harengus) Ph.D. thesis, Institute of Fisheries, University of Troms $\varnothing$, Troms $\varnothing$, Norway, 54

97. Roe SD (2001) Purification strategy. In Protein purification techniques (2ndedn), Roe S, Eds, Oxford University Press Inc, New York, 1-10.

98. Englard S, Seifter S (1990) Precipitation techniques. Methods in Enzymology Guide to Protein Purification, Deutscher MP, Eds, Academic Press Inc, San Diego, California, 182: 285-300.

99. Rossomando EF (1990) lon-exchange chromotrography. In Methods in Enzymology. Guide to Protein Purification, Deutscher MP, Eds, Academic Press Inc, San Diego, California 182: 309-316.

100. Stellwagen E (1990) Gel filtration. In Methods in Enzymology. Guide to Protein Purification, Deutscher MP, Ed, Academic Press Inc, San Diego, California 182: 317-328.

101. Bianchi M, Boigegrain RA, Castro B, Coletti-Previero M (1990) N-termina domain of pepsin as a model for retroviral dimericaspartyl protease. Biochem Biophys Res Commun167: 339-344.

102. Tanji M, Yakabe E, Kageyama T, Takahashi K (1996) The primary structure of the major pepsinogen from the gastric mucosa of tuna stomach. J Biochem 120: $647-656$

103.Doonan S (1996) Preparation of extracts from animal tissues. In Protein purification protocols, Doonan S, Ed, Humana Press Inc, Totowa, New Jersey, 17-22.

104. Chong ASC, Hashim R, Chow-Yang L, Ali AB (2002) Partial characterization and activities of proteases from the digestive tract of discus fish (Symphysodon aequifasciata). Aquaculture 203: 321-333.

105. Chiu S, Pan BS (2002) Digestive protease activities of juvenile and adult ee (Anguilla japonica) fed with floating feed. Aquaculture 205: 141-156.

106. Ersson B, Rydén L, Janson J (1998) Introduction to protein purification. In Protein purification: principles, high-resolution methods, and applications (2ndEdn), Janson J, Rydén L, Eds, John Wiely, Sons Inc, New York, 3-40.

107.Doonan S (2004) Bulk purification by fractional precipitation. In Protein purification protocols, Cutler P, Eds, Humana Press Inc, Totowa, New Jersey, 117-124.

108. Yamamoto S, Nakanishi K, Matsuno R (1988) lon-exchange chromatography of proteins, M. Dekker, New York,13-16.

109. Marshak DR, Kadonaga JT, Burgess RR, Knuth MW, Brennan WA (1996) Strategies for Protein Purification and Characterization: A Laboratory Course Manual, Cold Spring Harbor Laboratory Press, New York, 127-201.

110. Nalinanon S, Benjakul S, Visessanguan W, Kishimura H (2009) Partitioning of protease from stomach of albacore tuna (Thunnus alalunga) by aqueous two-phase systems. Process Biochem 44: 471-476.

111. Spelzini D, Farruggia B, Picó G (2005) Features of the acid protease partition in aqueous two-phase systems of polyethylene glycol-phosphate: chymosin and pepsin. J Chromatogr B 821: 60-66.

112. Tubío G, Nerli B, Picó G (2007) Partitioning features of bovine trypsin and a-chymotrypsin in polyethyleneglycol-sodium citrate aqueous two phase system. J Chromotogr B 852: 244-249.

113. Imelio N, Marini A, Spelzini D, Picó G, Farruggia B (2008) Pepsin extraction from bovine stomach using aqueous two-phase systems: Molecula mechanism and influence of homogenate mass and phase volume ratio. $J$ Chromatogr B 873: 133-138.

114. Tanuja S, Srinivas ND, RaghavaRao KSMS, Gowthaman MK (1997) Aqueous two-phase extraction for downstream processing of amyloglucosidase. Process Biochem 32: 635-641.

115. Albertsson P, Cajarville A, Brooks DE, Tjerneld F (1987) Partition of proteins in aqueous polymer two-phase systems and the effect of molecular weight of the polymer. Biochim Biophys Acta 926: 87-93.

116. Klomklao S, Benjakul S, Visessanguan W, Simpson BK, Kishimura H (2005) Partitioning and recovery of proteinase from tuna spleen by aqueous twophase systems. Process Biochem 40: 3061-3067. 
Citation: Zhao L, Budge SM, Ghaly AE, Brooks MS, Dave D (2011) Extraction, Purification and Characterization of Fish Pepsin: A Critical Review. J Food Process Technol 2:126. doi:10.4172/2157-7110.1000126

Page 14 of 14

117. Oliveira LA, Sarubbo LA, Porto ALF, Campos-Takaki GM, Tambourgi EB (2002) Partition of trypsin in aqueous two phase systems of polyethylene glycol and cashew-nut tree gum. Process Biochem 38: 693-699.

118. Rawdkuen S, Pintathong P, Chaiwut P, Benjakul S (2011) The partitioning of protease from Calotropis procera latex by aqueous two-phase systems and its hydrolytic pattern on muscle proteins. Food and Biopro Process 89: 73-80.

119. Richter C, Tanaka T, Yada RY (1998) Mechanism of activation of the gastric aspartic proteinases: pepsinogen, progastricsin and prochymosin. Biochem $\mathrm{J}$ 335: $481-490$

120. Sanny CG, Hartsuck JA, Tang J (1975) Conversion of pepsinogen to pepsin. Further evidence for intramolecular and pepsin-catalyzed activation. J Biol Chem 250: 2635-2639.

121. Fourie J, Arnot RS, Carter J, Hickman R, Terblanche J (1974) Measurement of pepsin in porcine gastric juice. S Afr Med J 48: 1873-1875.

122. Northrop JH (1932) Pepsin activity units and methods for determining peptic activity. J Gen Physiol 16: 41-58.
123. Lowry OH, Rosebrough NJ, Farr AL, Randall RJ (1951) Protein measurement with Folin phenol reagent. J Biol Chem 193: 256-275.

124. Bradford MA (1976) A rapid and sensitive method for the quantification of microgram quantities of protein utilizing the principle of protein dye binding Anal Biochem 72: 248-254.

125. Nigam A, Ayyagari A (2007) Lab manual in biochemistry, immunology and biotechnology; Tata Mgraw-Hill Publishing Company, New Delhi, 53-54.

126. Passonneau JV, Lowry O H (1993) Enzymatic analysis: A practical guide, The Humana Press Inc, Totowa, New Jersey, 229-306.

127. Speicher DW (2005) Electrophoresis. In Current protocols in protein science, Coligan, JE, Eds, John Wiley and Sons Inc, New York, 36-35.

128. Lineweaver H, Burk D (1934) The determination of enzyme dissociation constants. J Am Chem Soc 56: 658-666.

129. Chaiwut P, Rawdkuen S, Benjakul S (2010) Extraction of protease from calotropis procera latex by polyethylene glycol-salts biphasic system. Process Biochem 45: 1148-1155. 